\title{
Biofouling on Coated Carbon Steel in Cooling Water Cycles Using Brackish Seawater
}

\author{
Pauliina Rajala ${ }^{1, *}$, Elina Sohlberg ${ }^{2}$, Outi Priha ${ }^{2,+}$, Irina Tsitko ${ }^{2}$, Henri Väisänen ${ }^{3, \ddagger}$, \\ Mikko Tausa ${ }^{3}$ and Leena Carpén ${ }^{1}$ \\ 1 VTT Technical Research Centre of Finland Ltd., Materials Performance, 02150 Espoo, Finland; \\ leena.carpen@vtt.fi \\ 2 VTT Technical Research Centre of Finland Ltd., Process Microbiology and Safety, 02150 Espoo, Finland; \\ sohlberg.elina@gmail.com (E.S.); outi.priha@gmail.com (O.P.); irina.tsitko@vtt.fi (I.T.) \\ 3 Teollisuuden Voima Oyj, 27160 Eurajoki, Finland; henri.vaisanen@fennovoima.fi (H.V.); \\ mikko.tausa@tvo.fi (M.T.) \\ * Correspondence: pauliina.rajala@vtt.fi; Tel.: +358-20-722-111 \\ + Current address: European Chemicals Agency, Biocides Unit, 00121 Helsinki, Finland \\ $\ddagger$ Current address: Fennovoima Oy, Essential Water Systems, 00180 Helsinki, Finland \\ Academic Editors: Christine Bressy, Jean-François Briand, Gérald Culioli and André Margaillan \\ Received: 30 August 2016; Accepted: 2 November 2016; Published: 11 November 2016
}

\begin{abstract}
Water cooling utilizing natural waters is typically used for cooling large industrial facilities such as power plants. The cooling water cycles are susceptible to biofouling and scaling, which may reduce heat transfer capacity and enhance corrosion. The performance of two fouling-release coatings combined with hypochlorite treatment were studied in a power plant utilizing brackish sea water from the Baltic Sea for cooling. The effect of hypochlorite as an antifouling biocide on material performance and species composition of microfouling formed on coated surfaces was studied during the summer and autumn. Microfouling on surfaces of the studied fouling-release coatings was intensive in the cooling water cycle during the warm summer months. As in most cases in a natural water environment the fouling consisted of both inorganic fouling and biofouling. Chlorination decreased the bacterial number on the surfaces by 10-1000 fold, but the efficacy depended on the coating. In addition to decreasing the bacterial number, the chlorination also changed the microbial species composition, forming the biofilm on the surfaces of two fouling-release coatings. TeknoTar coating was proven to be more efficient in combination with the hypochlorite treatment against microfouling under these experimental conditions.
\end{abstract}

Keywords: microfouling; biofilm; cooling water; hypochlorite; fouling-release

\section{Introduction}

Water cooling using natural waters is typically utilized for cooling large industrial facilities such as power plants. Once-through systems are a common choice, when abundant water resources such as lakes, rivers, or seas are accessible. Industrial coolers are systems in which the excess heat is transferred through metal surfaces to colder, circulating water [1]. Cooling systems utilizing natural water are susceptible to biofouling, which refers to the undesirable accumulation of biotic deposits on a surface [2]. There is a known sequence of biofouling formation: first the surfaces are colonized by microorganisms that prepare the surface conditions suitable for settlement of other biofouling species [2,3]. Microfouling, i.e., microbial biofilm formation, on the surfaces of materials in the water cycles can enhance corrosion of these materials. In the industrial systems, the biofilm formation together with inorganic fouling and scaling can cause problems such as an increase in the flow resistance of pipelines or a decrease in the thermal transfer capacity of the heat exchangers [4]. It has 
been estimated that $20 \%$ of all corrosion damage of the heat exchangers is caused or influenced by microorganisms [4]. The efficiency and availability of a power plant depends to a great extent on the performance and cleanness of materials used. More than $5 \%$ of the efficiency of a power plant can be lost due to biofouling on surfaces [5].

Chemical cleaning of the affected area is the main method used for removing unwanted biofilms in the cooling water systems. Currently the most common biocide to prevent biofouling in once-through cooling systems is hypochlorite $[5,6]$. The biocidal effect of hypochlorite is due to its oxidative effect that causes it to react with bromide, which is naturally present in seawater and also possibly with other compounds, both organic and inorganic, leading to the formation of hypobromite and halogenated organic compounds [5,7]. The high oxidative power of the hypobromite, formed through the above-mentioned reaction, cause fast inactivation of enzymes and other cellular components of microorganisms. The usage of hypochlorite, however, raises environmental concerns due to production of by-products that are toxic to aquatic organisms $[7,8]$.

In addition to biocides, biofouling may be prevented by application of coatings developed to prevent the settlement of fouling organisms. The functionality of coatings is based on either biocide release, which inhibits fouling settlement by releasing biocidal products into the marine environment, or nontoxic fouling release coatings, whose antifouling efficiency relies on low adhesion strength and easy release of fouling organisms from such a coating [9]. Coatings also allow the use of less corrosion resistant metals such as carbon steel, since the base material is not in direct contact with seawater. However, biofilm forming microorganisms are known to deteriorate various polymeric materials, including some coating materials [10,11]. Even though the microfouling species would not directly cause deterioration of the coatings, the original antifouling properties such as hydrophobicity of surface can be masked [10].

For effective antifouling treatment, all factors including the environmental impact of biocides and the cost of biocide treatments and antifouling coatings have to be considered [7]. Given the costs of biofouling treatment, power plants require biofouling and biocorrosion control solutions that are economically efficient, easy to apply to the system, as well as environmentally sustainable. This can be achieved by adjusting the timing and magnitude of chlorination in combination with special antifouling surfaces [6,12-14]. There is a need, however, for deeper understanding of the structure of the microbial community responsible for biofouling of the surfaces under real industrial conditions.

The aim of this research was: (1) to compare the suitability of two commercially available coatings to be used in cooling water systems using hypochlorite as a biocide; (2) to characterize the primary biofilm forming a microbial community in system with or without a hypochlorite treatment and on different coatings. Here we focused on microbial fouling community (bacteria, archaea, and fungi) that attached to the surface of coated (fouling release) carbon steel in a power plant utilizing brackish seawater from the Baltic Sea. Hypochlorite treatment was used to prevent biological fouling in the cooling water system during summer months, when the seawater temperature rises and biofouling is more intensive. The results of a three-month survey of the effect of chlorination on coating performance and species composition of microfouling on coated surfaces are presented and discussed.

\section{Materials and Methods}

\subsection{Materials}

The test material was coated with low alloy carbon steel (corresponding with the composition of carbon steel AISI 1005) from cold-rolled thin sheet $(1 \mathrm{~mm})$. The surface of the carbon steel was as received and the coupon size was $25 \mathrm{~mm} \times 75 \mathrm{~mm}$. Two different coatings, a biocide free silicon coating, BioCleanEco (CMP, Tokyo, Japan) and a synthetic purified epoxy tar coating TeknoTar100 (Teknos, Helsinki, Finland), were applied to the carbon steel specimens as instructed by the manufacturers. The coupons were cleaned with the FreeBact-20 (AquaFix, Satsjöbaden, Sweden) and sterile ultra pure water and air-dried before exposure. Each biofouling cell contained eight coupons of each coating. 
Three parallel coupons were used for material analyses, three coupons for molecular biological analyses, and two for microscopy subsequently. The coupons were photographed prior to the experiment.

\subsection{Experimental Procedure}

To study the fouling in the cooling water cycle, a specially developed biofouling cell was installed into the cooling water cycle (Figure 1) at a power plant where the hypochlorite treatment is routinely used to control biofouling. Two units were installed in the cycle before the chlorination point ("controls") and two units after the hypochlorite dosage point ("hypochlorite"). The water flow through the biofouling cell was $0.1 \mathrm{~m} \cdot \mathrm{s}^{-1}$.

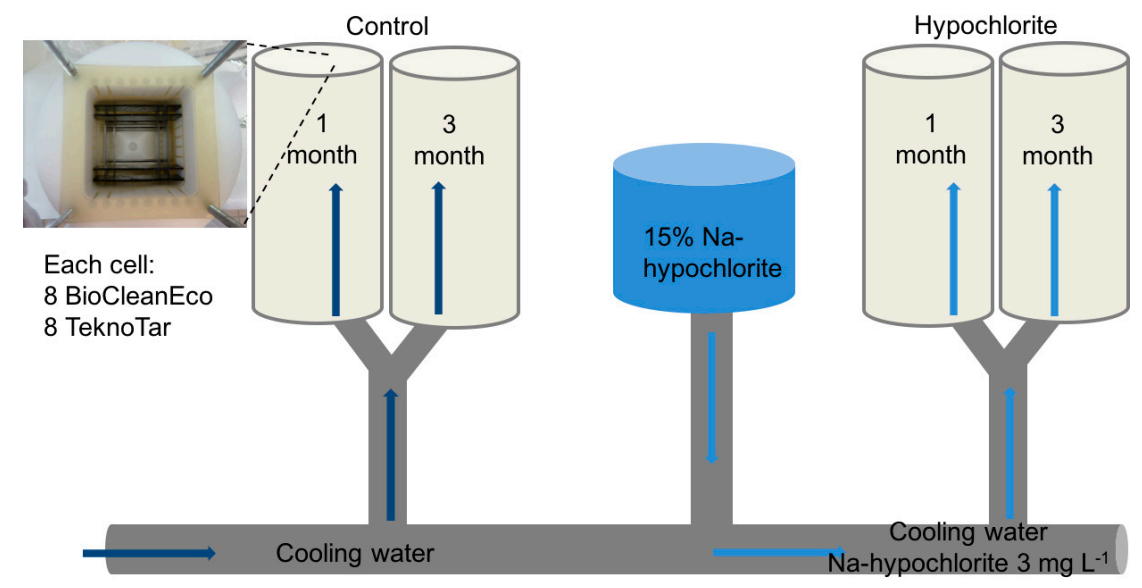

Figure 1. Schematic illustration of experiment setup. Not in scale.

Na-hypochlorite $(15 \%)$ was dosed in the cooling system to obtain a final target concentration of $3 \mathrm{mg} \cdot \mathrm{L}^{-1}$. During the first 30 days chlorination was applied for two hours with $10 \mathrm{~h}$ breaks between the treatments, and after that for one hour with $11 \mathrm{~h}$ breaks in between. The experiment period started at July 2014, a week after chlorination had already started. The first set of biofouling cells, one control cell and one cell after the hypochlorite dosage point were removed from the cooling water cycle after 32 days of exposure (one month). The second sampling was performed after 90 days of exposure (3 months). The biofouling cells were removed from the water cycle and sealed so that water remained inside the cells. The cells were dismantled aseptically in the laboratory.

The temperature of seawater used for cooling (seawater IN) and the temperature of cooling water after the cycle (seawater OUT) were monitored continuously during the experiment period. The chemical parameters of seawater used for cooling were measured once a month during the experiment period.

\subsection{Surface Characterization}

The coupons for the material studies were immersed in 96\% ethanol, air-dried, and stored in a glass desiccator until studied. All coupons for material analyses were photographed and examined with a stereomicroscope.

The condition of the exposed coated surfaces was examined using a Zeiss ULTRAplus field emission scanning electron microscope (Carl Zeiss Microscopy GmbH, Jena, Germany).

For the confocal microscopy, the samples were gently rinsed in water and stained with the DNA specific fluorescence dye SYTO9 (Thermo Fisher Scientific, Eugene, OR, USA) for $25 \mathrm{~min}$ in dark at room temperature. Visualization of the biofilms was done by confocal laser scanning microscopy (CLSM) using a Zeiss LSM 710 microscope (Carl Zeiss Microscopy GmbH) using the EC Epiplan-Neofluar $20 \times 0.5 \mathrm{NA}$ or the $63 \times 0.9 \mathrm{NA}$ (oil) objectives. The $488 \mathrm{~nm}$ Ar laser was used and a green emission was collected at $498-566 \mathrm{~nm}$. The images were acquired and analyzed using the ZenPro (black edition) 
software (Carl Zeiss Microscopy GmbH). Z-stacks (vertical sections) were recorded with the optimal parameters suggested by the software. The number of the Z-stacks depended on the biofilm thickness. Auto-fluorescence of the coatings was checked using unused samples. The TerknoTar100 coating showed auto-fluorescence in the green area of the spectrum.

\subsection{DNA Extraction}

The coupons for microbiological analyses were subjected to the biofilm extraction immediately after they were removed from the biofouling cell. The biomass from the coupon surfaces was removed by brushing for $60 \mathrm{~s}$ using Omron Sonic Style B458 brush (Omron, Wegalaan, The Netherlands). The brushes were placed aseptically into tubes containing $20 \mathrm{~mL}$ sterile Ringer-solution (Merck, Darmstadt, Germany). The tubes were subsequently vortexed for $60 \mathrm{~s}$. The suspension containing the biomass was filtered on the Sterivex filter unit (Sterivex-GP $0.22 \mu \mathrm{m}$; Millipore, Billerica, MA, USA). From both sampling times (32 days and 90 days) $500 \mathrm{~mL}$ of chlorinated and non-chlorinated seawater was filtered onto Sterivex or Corning (Corning $0.22 \mu \mathrm{m}$ CA 430626/PES 431161; Corning, NY, USA) filter units as two replicates. Sterivex filtering units and Corning filters were cut with a sterile scalpel and stored frozen $\left(-80^{\circ} \mathrm{C}\right)$ until DNA extraction. For DNA extraction, Sterivex filter units were aseptically broken with a hammer, and both Sterivex and Corning filters were cut into pieces and placed into the lysing tube of the DNA extraction kit. The DNA extraction was performed using a Fast DNA Spin kit for soil (MP Biomedicals, Santa Ana, CA, USA) according to manufacturer's protocol with the modification that the cells were homogenised in a FastPrep-24 instrument (MP Biomedicals, Santa Ana, CA, USA) at $6 \mathrm{~m} \cdot \mathrm{s}^{-1}$ for $3 \mathrm{~min}$.

\subsection{Quantitative PCR}

The number of bacteria forming biofilm on the surfaces was estimated by quantitative polymerase chain reaction (qPCR) of bacterial $16 \mathrm{~S}$ ribosomal RNA (rRNA). An approximately $200 \mathrm{bp}$ fragment of the 16S rRNA gene was amplified with primers 358F and 534R [15] and detected with SYBR green based detection of double-stranded DNA, using LightCycler ${ }^{\circledR} 480$ qPCR machine (Roche Diagnostics, Basel, Switzerland). The DNA concentration of all samples was measured with Nanodrop 2000 spectrophotometer (Thermo Fisher Scientific) and adjusted to $\leq 10 \mathrm{ng} \cdot \mu \mathrm{L}^{-1}$ with molecular-biology-grade water (Sigma, St. Louis, MO, USA) prior to qPCR in order to avoid PCR inhibition. The $10-\mu \mathrm{L}$ reaction mixture contained $1 \mu \mathrm{L}$ of DNA template, $1 \times \mathrm{KAPA}_{\text {SYBR }}{ }^{\circledR}$ FAST Universal qPCR Master Mix (KAPA Biosystems, MA, USA), and $150 \mathrm{nM}$ of both primers. The PCR program consisted of initial $15 \mathrm{~min}$ incubation at $95^{\circ} \mathrm{C}$, followed by 45 cycles of denaturation at $95^{\circ} \mathrm{C}$ for $10 \mathrm{~s}$, annealing at $57^{\circ} \mathrm{C}$ for $35 \mathrm{~s}$ and extension at $72{ }^{\circ} \mathrm{C}$ for $30 \mathrm{~s}$, followed by a final extension at $72{ }^{\circ} \mathrm{C}$ for $3 \mathrm{~min}$ and a melting curve analysis. As an external standard, a dilution series (100-10 colony forming units (cfu) $\mu \mathrm{L}^{-1}$ ) of Escherichia coli VTT E-90418 genomic DNA was used. The results were calculated using Absolute quantification/second derivative maximum in LightCycler ${ }^{\circledR} 480$ Software 1.5.0 (Roche Diagnostics). The statistical significance of differences of the means was calculated applying two-way ANOVA (IBM SPSS Statistics version 21, Armonk, NY, USA).

\subsection{Amplification Library Preparation}

The amplification libraries for high-throughput sequencing with Ion Torrent PGM were prepared by PCR from the DNA samples. Bacterial 16S rRNA genes were amplified with the primers [16], targeting the variable region V3-V4 of the 16S rDNA gene, archaeal 16S rRNA genes with the primers [17], targeting the V4 region of the gene and fungal internal transcribed spacer (ITS) gene markers with the primer pair ITS1 and ITS2 targeting the fungal ITS1 region [18]. PCR amplification was performed in parallel $25 \mu \mathrm{L}$ reactions for every sample containing $1 \times$ MyTaq $^{\mathrm{TM}}$ Red Mix (Bioline, London, UK), 20 pmol of each primer, up to $25 \mu \mathrm{L}$ molecular-biology-grade water (Sigma) and $2 \mu \mathrm{L}$ of template. The PCR program consisted of an initial denaturation step at $95{ }^{\circ} \mathrm{C}$ for $3 \mathrm{~min}$, 35 cycles for bacteria and fungi, and 40 cycles for archaea of $15 \mathrm{~s}$ at $95{ }^{\circ} \mathrm{C}, 15 \mathrm{~s}$ at $50{ }^{\circ} \mathrm{C}$, and $15 \mathrm{~s}$ 
at $72{ }^{\circ} \mathrm{C}$. A final elongation step of $30 \mathrm{~s}$ was performed at $72{ }^{\circ} \mathrm{C}$. The PCR products were verified with agarose gel electrophoresis. Amplicons were sequenced using Ion Torrent PGM sequencing platform (Thermo Fisher Scinetific) at Bioser (University of Oulu, Finland) and amplicons were purified before sequencing.

\subsection{Sequence Processing and Analysis}

The sequence reads obtained from Ion Torrent sequencing were first subjected to quality control using the QIIME software [19]. During this step, adapters, barcodes, and primers were removed from the sequence reads, and the quality of base-calls was assessed in order to remove erroneous reads from the data set. Subsequently, chimeric sequence reads, which are a type of sequencing artefact arising from sequences from separate sources fusing into one, were removed from the data set with the USEARCH algorithm version 5.2.236 [20] by de novo detection and through similarity searches against the Greengenes reference database [21] with bacterial and archaeal sequences and UNITE database [22] with fungal sequences.

Groups of similar sequences-i.e., Operational Taxonomic Units (OTUs)—were selected from the chimera-filtered sequence data set following open-reference OTU-picking protocol of QIIME version 1.8.0 against the $97 \%$ identity Greengenes or UNITE reference database sets. OTU clustering was performed with UCLUST version 1.2.22q [20] and the seed sequences were selected as the representative OTU sequences. All reads that failed to hit the Greengenes or UNITE reference database with a minimum of $60 \%$ identity threshold were discarded as sequencing error. Next, singleton OTUs-i.e., OTUs that were represented by a single sequence-were filtered from the data set. Finally, taxonomy from the domain-level up to species-level was assigned to OTUs via representative OTU sequences with the Ribosomal Database Project classifier algorithm at minimum of $80 \%$ confidence [23] with bacterial and archaeal sequences. With fungal ITS sequences, taxonomic assignments were made by the BLASTN algorithm with a maximum $E$-value of 0.001 [20].

\section{Results}

\subsection{Seawater Characteristics}

Seawater temperature varied between 15 and $25{ }^{\circ} \mathrm{C}$ for the first 70 days, after which the temperature gradually decreased to $5^{\circ} \mathrm{C}$ by the end of the experiment period (Figure 2). Conductivity of seawater was $1010-1020 \mathrm{mS} \cdot \mathrm{m}^{-1}$, salinity $5.8 \%-5.9 \%$, $\mathrm{pH} 8$, alkalinity $1.4 \mathrm{mmol} \cdot \mathrm{L}^{-1}$, and total organic carbon content $4-4.2 \mathrm{mg} \cdot \mathrm{L}^{-1}$ during the experiment period.

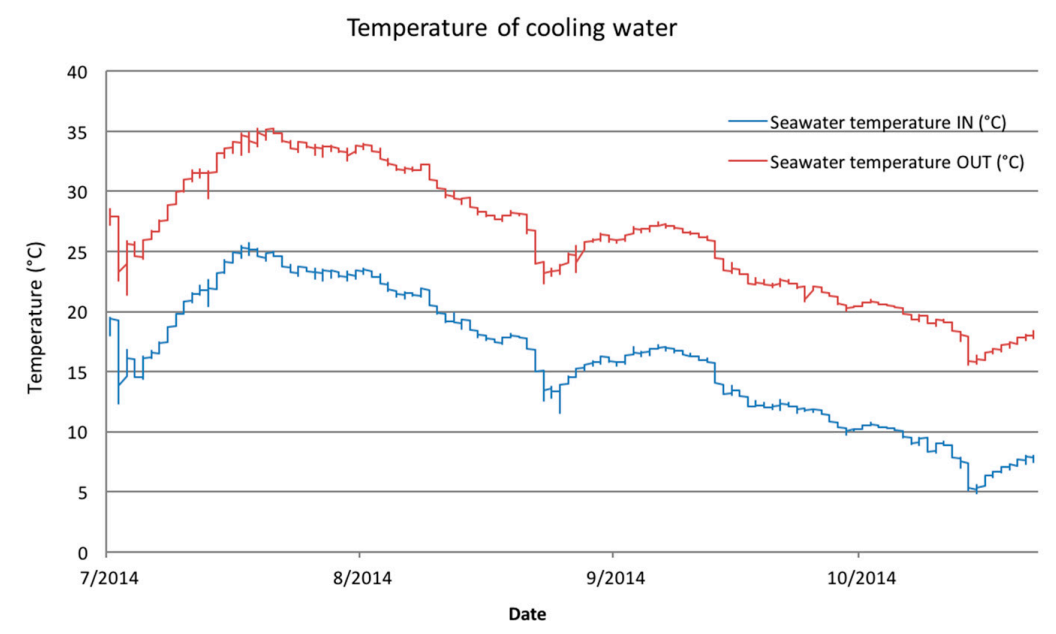

Figure 2. Temperature of seawater used for cooling (IN) and temperature of the seawater after cooling circle (OUT). 


\subsection{Performance of the Coatings}

The fouling on the coatings was examined using a stereo-microscope and a confocal microscope. The inspection revealed fouling on all surfaces (Figures 3 and 4). However, the fouling was less intensive on the hypochlorite-treated surfaces and had an even appearance whereas in the untreated samples the fouling was present in form of thicker patches on the surfaces (Figure 4). No visual difference between the BioCleanEco and TeknoTar coatings could be observed (Figure 3).

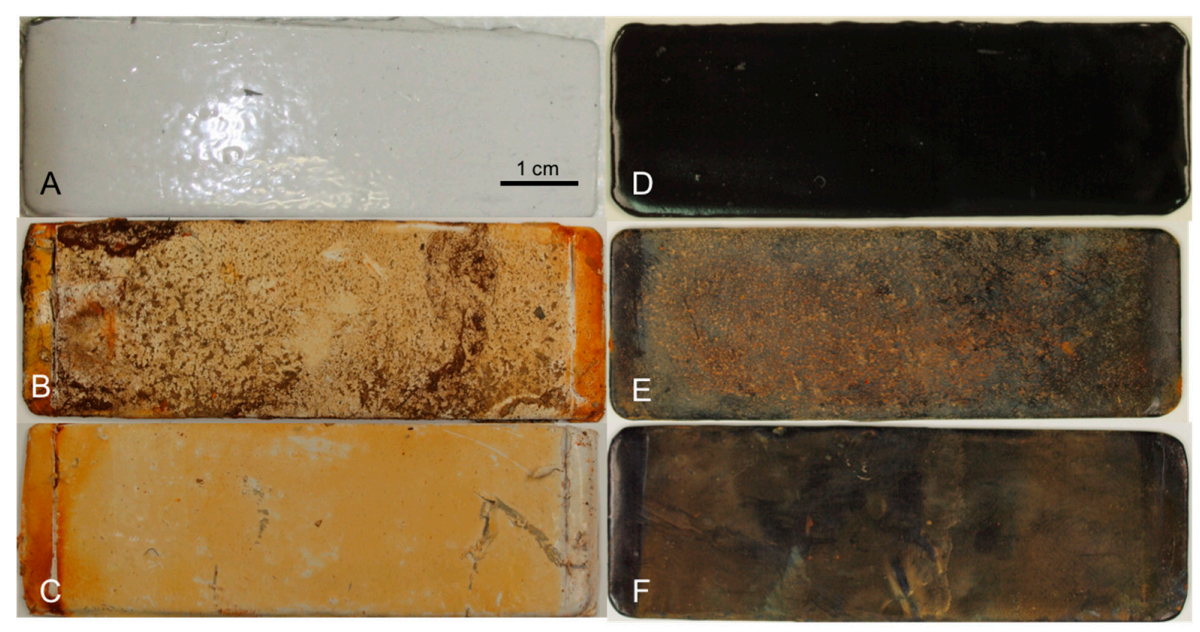

Figure 3. Specimens before (A,D) and after the three-month experiments (B,C,E,F). First column shows BioCleanEco coating (white coating), and second column shows TeknoTar coating (black coating). In addition, $(\mathbf{B}, \mathbf{E})$ and $(\mathbf{C}, \mathbf{F})$ show specimens exposed to control and hypochlorite systems, respectively.

The deposit on the surfaces formed a thin uniform light brown layer on all surfaces (Figure 4) in the hypochlorite-treated environment. In the untreated control system, the thicker dark brown deposits partly covered the surfaces. The deposits resembling both inorganic fouling and biofouling were detected on all surfaces.

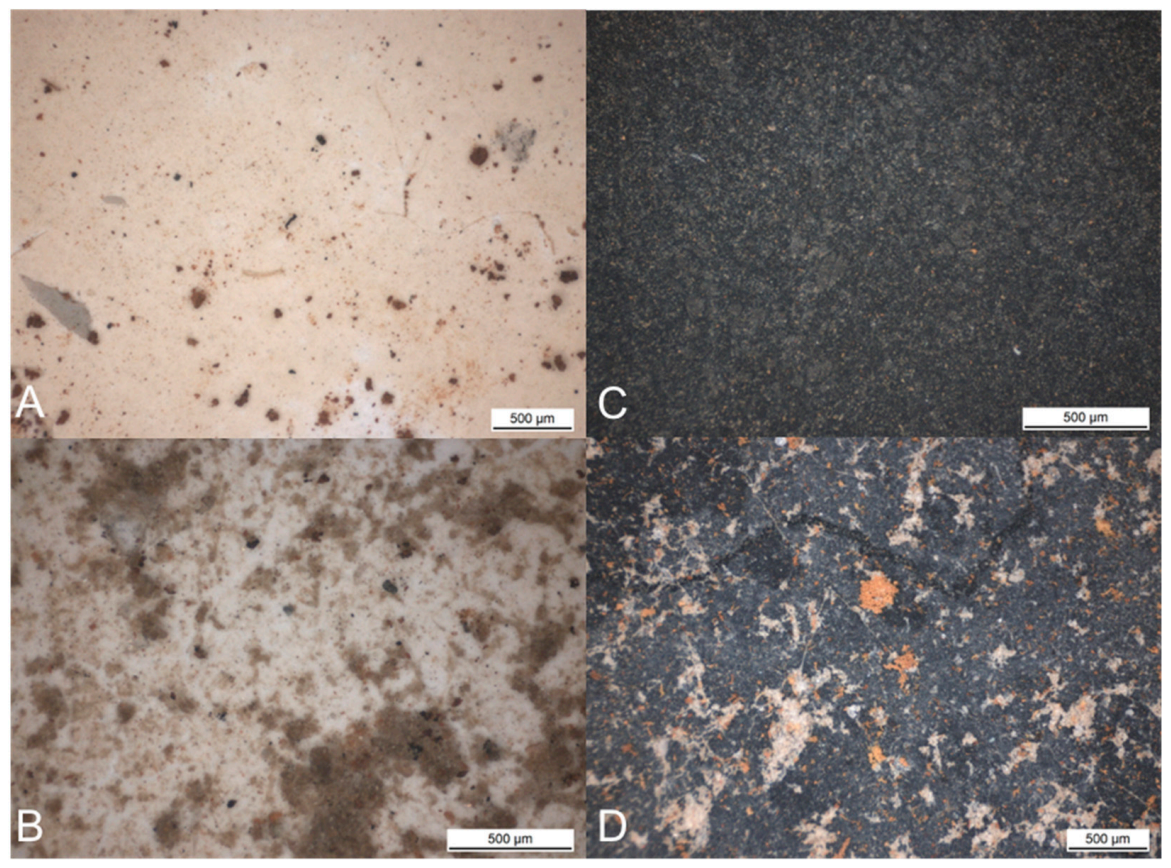

Figure 4. Fouling on surfaces of BioCleanEco coated specimens (A,B) and TeknoTar coated specimens $(\mathbf{C}, \mathbf{D})$, hypochlorite system $(\mathbf{A}, \mathbf{C})$ and control system (B,D). 
The confocal microscopy analyses revealed that the biofilms were formed on both the BioCleanEco and on the TeknoTar coated samples exposed to the untreated control system (Figures 5 and 6). The detected biofilm was uneven and ranged between $2 \mu \mathrm{m}$ and $35 \mu \mathrm{m}$ in thickness. No difference between the biofilms formed on the TeknoTar coating during one month and three months of the exposure to the control system was observed (Figure 6). Slightly better formed microcolonies were found on the surface of BioCleanEco coated samples after three-month exposure (Figure 5A,B).

Hypochlorite treatment of cooling water clearly reduced biofouling of the BioCleanEco surfaces. After a one-month exposure, detectable biofilm was formed on the surface (Figure 5A). After a three-month exposure, the fouling in hypochlorite-treated coupons was substantially reduced as compared to the control system (Figure 5B). There was, however, accumulation of organic matter on the surface on three-month old BioCleanEco coating, as unspecific fluorescence was seen under the microscope (Figure 5B).
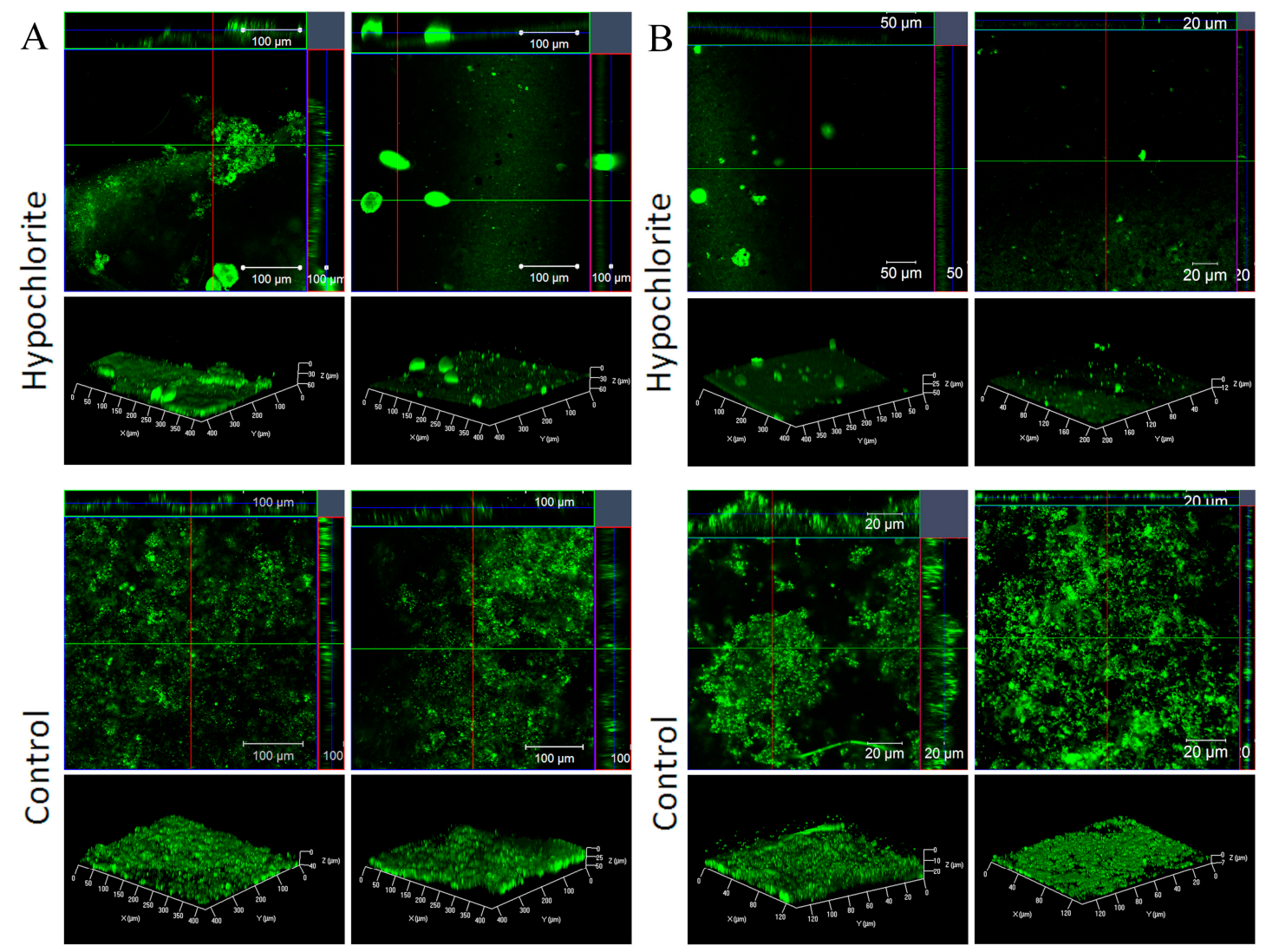

Figure 5. Confocal microscopy images of biofilm on the surface of BioCleanEco coated specimens. The biofilms were washed and stained with SYTO9, and Z-stacks of each were acquired by confocal laser scanning microscopy (CLSM). Upper panels, orthogonal projections of Z-stacks; bottom panels, 3D projections. Two random microscope fields are presented, (A) after one month; (B) after three months.

The effect of hypochlorite treatment on the biofouling of the TeknoTar coating was also notable-only small number of microorganisms was seen on the surfaces (Figure 6). There were also surface areas free of fouling. The accumulation on the organic layer on the TeknoTar surface was difficult to judge due to the autofluorescence of the TeknoTar coating. 

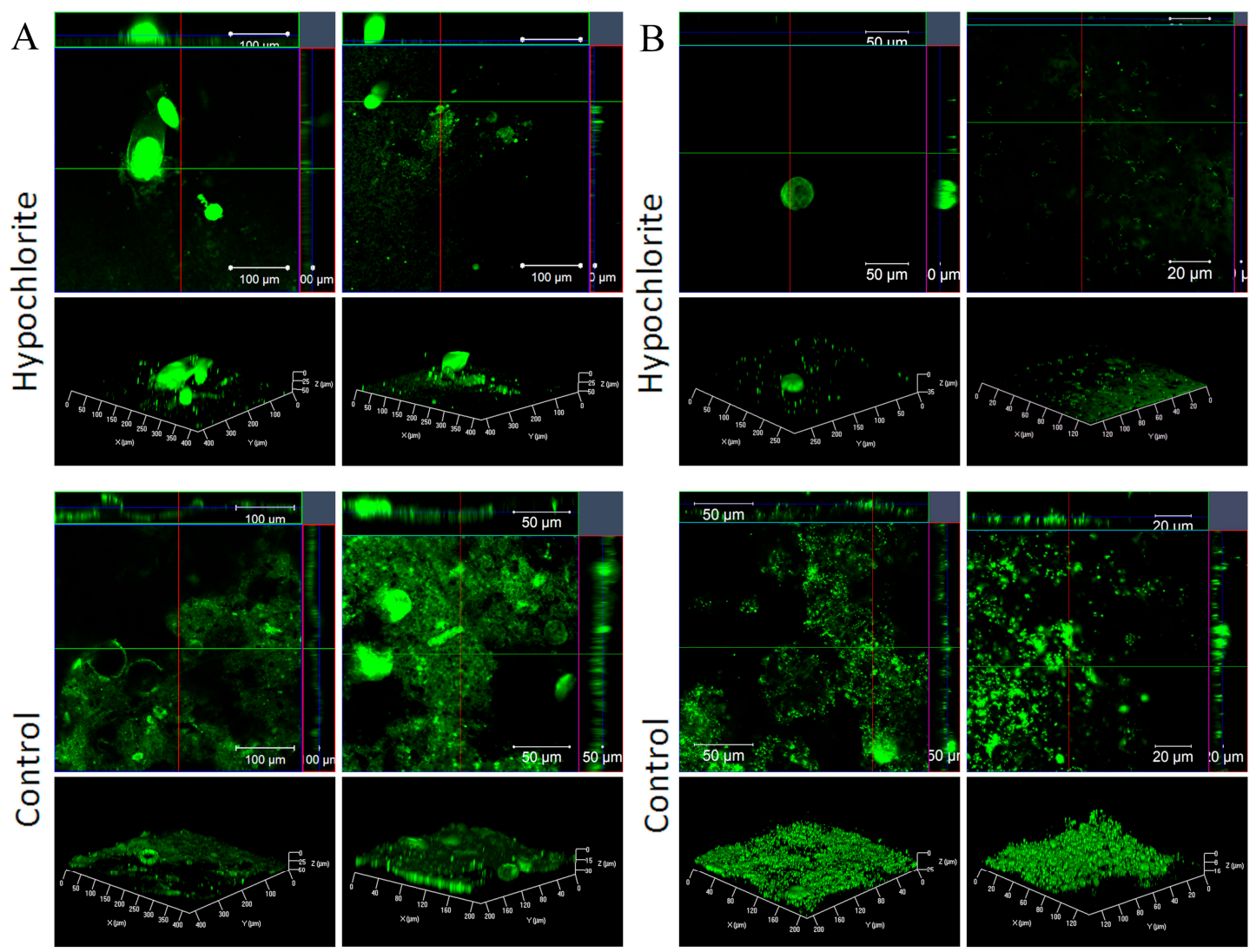

Figure 6. Confocal microscopy images of biofilm on the surface of TeknoTar coated specimens. The biofilms were washed and stained with SYTO9, and Z-stacks of each were acquired by CLSM. Upper panels, orthogonal projections of Z-stacks; bottom panels, 3D projections. Two random microscope fields are presented, (A) after one month; (B) after three months.

The condition of cleaned coated surfaces after the experiment was studied using Scanning Electron Microscopy (SEM). No coating damage due exposure or hypochlorite treatment was observed compared to the unexposed coated specimens.

\subsection{Characterization of Microbial Population}

Seawater, both hypochlorite-treated and controls, contained $2 \times 10^{7}$ bacteria $\cdot \mathrm{mL}^{-1}$ at the one-month sampling, and $7 \times 10^{6}$ bacteria $\cdot \mathrm{mL}^{-1}$ at the three-month sampling, as determined by qPCR of the 16S rRNA gene. The number of bacteria on the coupons from untreated control system was at the level of $10^{8} \mathrm{~cm}^{2}$ (Figure 7). Hypochlorite treatment reduced the bacterial numbers on the surfaces by 10-1000 fold, depending on the coating and exposure time. Lowest number of bacteria, $10^{4} \mathrm{~cm}^{2}$, was detected from TeknoTar coatings in hypochlorite-treated system exposed for three months. When interpreting the results from the quantitative PCR assay, it must be borne in mind that the $16 \mathrm{~S}$ rRNA gene copy numbers vary in different microbial species. Thus, the results do not give absolute cfu numbers, but still give an overview estimate of the trend and can be well used for comparing different treatments. 
A

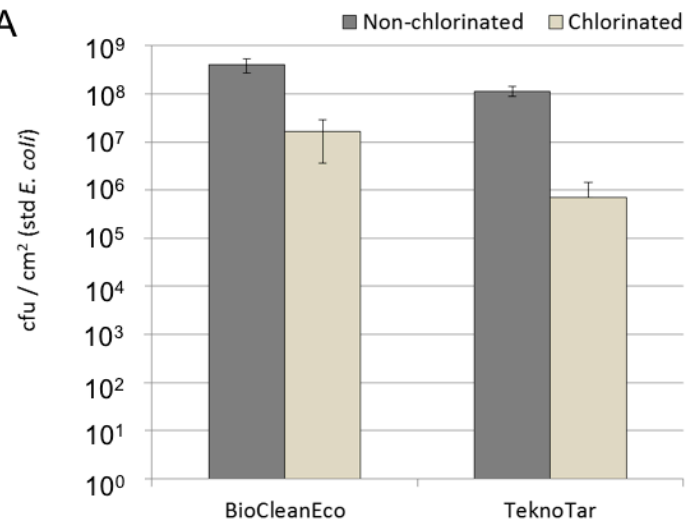

B

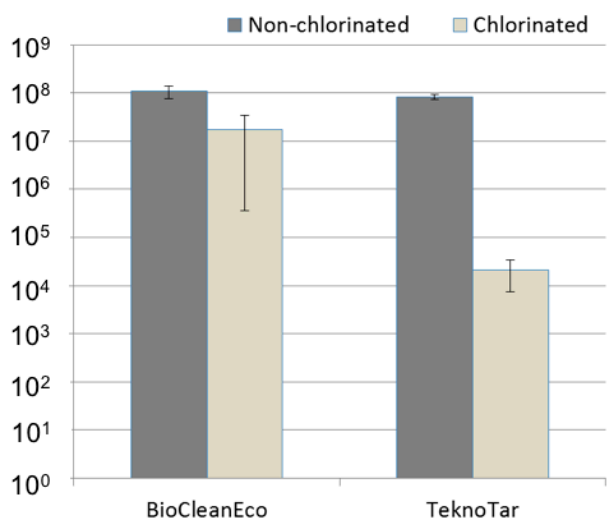

Figure 7. Numbers of bacteria on coupon surfaces after (A) one-month and (B) three-month exposure in control system or hypochlorite-treated sea water, as determined using quantitative PCR. Bars show standard deviations; cfu: colony forming units.

The diversity of bacterial, archaeal, fungal, and other eukaryotic communities from biofilms growing on the coupons both from the hypochlorite-treated and the untreated control system, were studied using DNA-based high-throughput amplicon sequencing analysis. The total number of bacterial OTUs was 14,409; archaeal OTUs 10,891; and fungal OTUs 5267. From the bacterial sequencing the highest Shannon diversity index $\left(H^{\prime}=7.3\right)$, which indicates the abundance and evenness of the species present, was obtained from the hypochlorite-treated and control system TeknoTar coupons after a one-month exposure. The lowest bacterial diversity $\left(H^{\prime}=4.1\right)$ was detected on the hypochlorite-treated BioCleanEco coupons after a three-months exposure. The highest archaeal diversity $\left(H^{\prime}=6.7\right)$ was detected on BioCleanEco coupons from control system after a one-month exposure and lowest on the hypochlorite-treated TeknoTar coupons $\left(H^{\prime}=0-2.9\right)$. Fungal diversity $\left(H^{\prime}=6.6\right)$ was highest on the hypochlorite-treated BioCleanEco coupons after one month of exposure and lowest $\left(H^{\prime}=0.9\right)$ in the hypochlorite-treated TeknoTar coupons after a one-month exposure. When comparing the Chao1 OTU richness estimate values to true detected OTU numbers, $44 \%-66 \%$ of bacterial, $47 \%-100 \%$ of the archaeal, and $47 \%-100 \%$ fungal estimated OTUs were obtained from the subsampled sequence data, meaning that sequencing depth was sufficient enough to fully characterize the microbial communities in most of the samples.

The main bacterial group in the biofilms growing on both the hypochlorite-treated and control coupons was Proteobacteria- $70 \%-96 \%$ of identified sequences (Figure 8 ). The bacterial community forming biofilm on the TeknoTar and BioCleanEco coupons in control system, comprised of Alphaproteobacteria $(42 \%-87 \%)$, with Rhodobacteraceae being the most common family after both a one-month and three-month exposure. After a one-month exposure, Acidobacteria ( $5 \%-20 \%)$, with Solibacterales as a most common family, was identified on surfaces of coupons from control system. Also, species belonging to Betaproteobacteria group $(6 \%-17 \%)$ were present after a one-month exposure but were not detected after a three-month exposure. Gammaproteobacteria $(4 \%-32 \%)$ were detected after a one-month exposure on surface of BioCleanEco and after three months of exposure on surface the of TeknoTar coupons from control system. Species belonging to the class Flavobacteriia $(2 \%-8 \%)$ of the phylum Bacteroidetes were present on both, BioCleanEco and TeknoTar coupons, in the control system exposed for three months.

In the hypochlorite-treated coupons, the main bacterial group was Alphaproteobacteria $(19 \%-76 \%)$ but unlike in coupons from the control system, more species from the phylum Betaproteobacteria were detected $(10 \%-28 \%)$, especially on the hypochlorite-treated BioCleanEco coupons. More species belonging to the class Gammaproteobacteria $(19 \%-65 \%)$ were identified on hypochlorite-treated BioCleanEco coupons than control system. The number of Flavobacteriia was 
higher in hypochlorite-treated coupons especially on BioCleanEco coupons after a one-month exposure. No species from the phylum Acidobacteria were detected in hypochlorite-treated coupons.

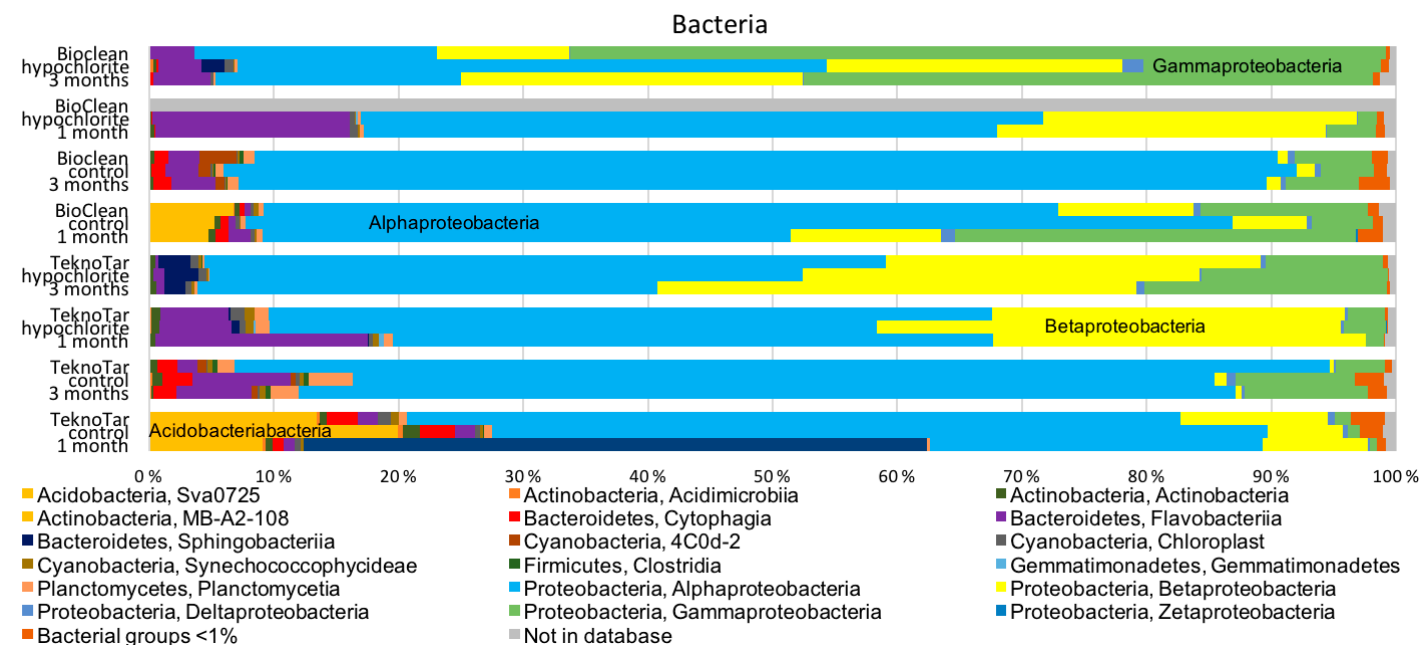

Figure 8. The bacterial community composition on surfaces of BioCleanEco coating and TeknoTar coating in hypochlorite-treated cooling water system and in control system.

Archaeal communities in the control environment on the surfaces of TeknoTar and BioCleanEco coated coupons were quite similar (Figure 9). Sequences affiliating with the phylum Crenarchaeota (43\%-97\%) dominated the archaeal community in all of the coupons after a one-month exposure. Also, species from Thaumarcheaota and Miscellaneous Crenarchaeota group (MCG) classes were detected and the most common family was Nitrosopumilus. Other major archaeal group, especially on the control coupons exposed for three months was the phylum Euryarchaeota with Methanomicrobia ( $20 \%-54 \%)$ being the most common class detected. Species from Methanosarcina, Methanocella, and Methanoculleus were most common families identified. Archaeal population extracted from the hypochlorite-treated coupons differed from archaeal population from the control system. Main archaeal group in the biofilms extracted from the hypochlorite-treated TeknoTar and BioCleanEco coupons was Crenarchaeota but only below $2 \%$ of sequences were identified as Euryarchaeota. In addition, in the TeknoTar coupons, sequences belonging to Parvarcheaota $(4 \%-11 \%)$ were observed. A large number of archaeal sequences remained unidentified (19\%-59\%) from both TeknoTar and BioCleanEco samples, but this can be due to insufficient representation of archaeal sequences in the sequence databases.

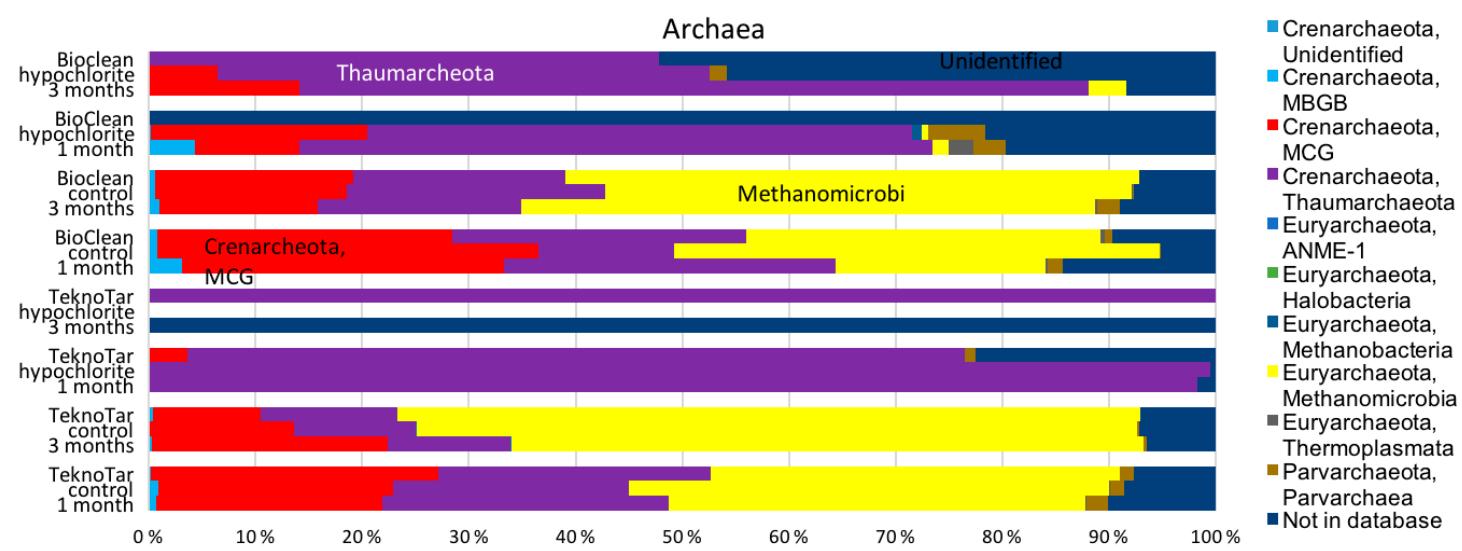

Figure 9. The archaeal community composition on surfaces of BioCleanEco coating and TeknoTar coating in hypochlorite-treated cooling water system and in control system. 
After one month of exposure in the control system, the most common fungal classes identified on the surfaces of the TeknoTar coupons were unidentified Ascomycota group (7\%-16\%) and Dothideomycetes (3\%-10\%), with Cladosporium as the most common family detected (Figure 10). After three months of exposure, the dominating fungal classes on the TeknoTar coupons were Monoblepharidomycetes ( $9 \%-45 \%)$ and Blastocladiomycetes (60\% in one sample). Most common fungal group on the BioCleanEco coupons from control system exposed for one month were unidentified Ascomycota group (7\%-23\%) and after three months, Monoblepharidomycetes (11\%-27\%). Only small differences of fungal communities between the control system and the hypochlorite-treated coupons were detected. The most common fungal groups on the hypochlorite-treated TeknoTar and BioCleanEco coupons were unidentified Ascomycota group (9\%-63\%) and species from Monoblepharidomycetes group (3\%-55\%). In addition, after three months of exposure on the hypochlorite-treated TeknoTar surfaces, species belonging to the Malasseziales order (34\% in one sample) were detected. A large number of fungal sequences remained unidentified in all coupons $(13 \%-84 \%)$.

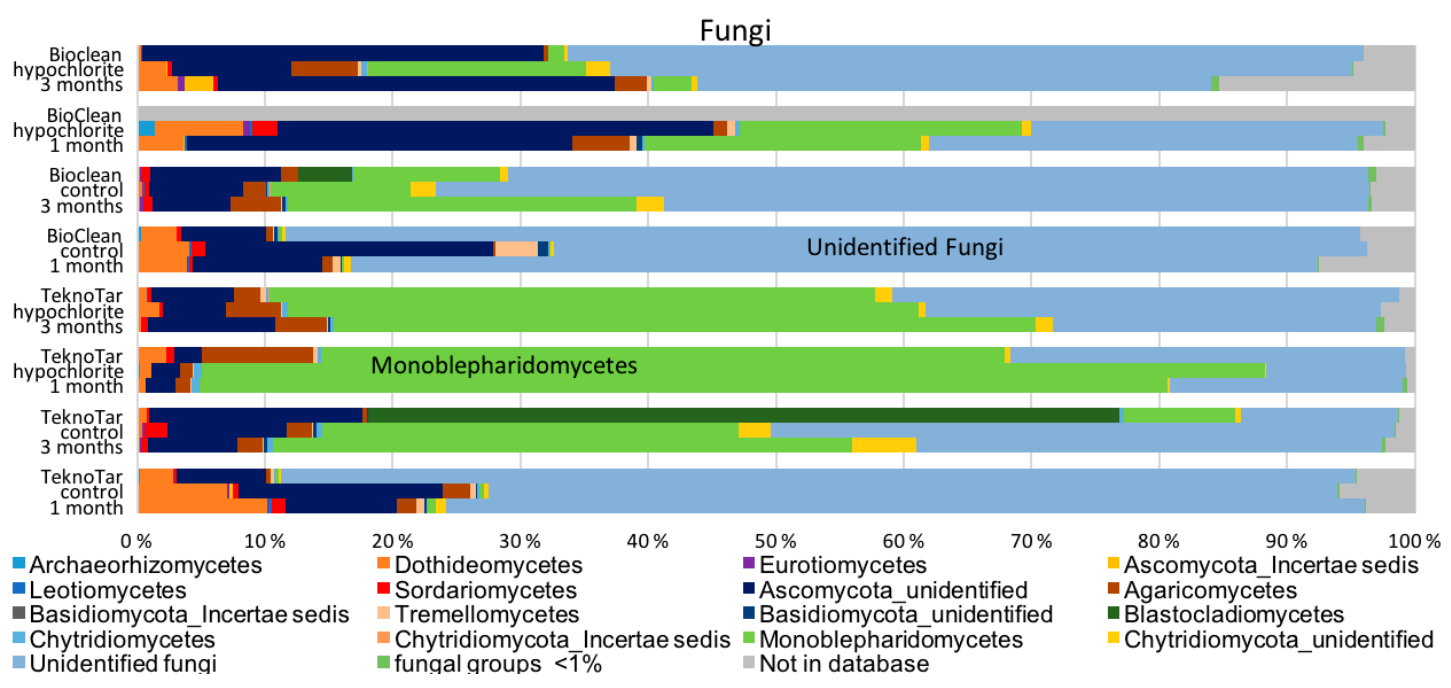

Figure 10. The fungal community composition on surfaces of BioCleanEco coating and TeknoTar coating in in hypochlorite-treated cooling water system and in control system.

\section{Discussion}

Microfouling on the surfaces of studied anti-fouling coatings was intensive in the cooling water cycle during the warm summer months. As in most cases in natural water environments the fouling was formed by both inorganic fouling and biofouling. The formed biofilm was thick on the surfaces of untreated control samples. Our results indicated that the amount of bacteria on the surfaces from the control system was $10^{8}$ cells $\cdot \mathrm{cm}^{-2}$. Similar numbers of bacterial microfouling have been reported on anti-fouling surfaces in oceanic waters, also in much warmer sites [24-26]. Hypochlorite treatment reduced the bacterial numbers by 10-1000-fold, but the efficiency depended on the coating. The combination of TeknoTar coating and hypochlorite treatment was most efficient in reducing the attachment of bacteria, causing a 100-1000-fold decrease in number of attached bacteria compared to the untreated control, depending on the exposure time. With BioCleanEco the difference between the untreated control and hypochlorite-treated samples was 10-fold at both exposure times. The confocal results suggest that the chlorination of the cooling water probably did not prevent the bacterial adherence to the surface, but rather killed cells later, resulting in accumulation of the cell debris on the surface.

Biocidal coatings have been demonstrated to decrease the bacterial diversity of a microfouling community when compared to biocide-free coating [27]. The antifouling coating used here did not 
produce as straightforward results combined with the hypochlorite treatment. The highest bacterial diversity was detected on TeknoTar coatings after a one-month exposure irrespective to whether they had received a hypochlorite treatment or not, even though the number of bacteria was significantly decreased due to the hypochlorite. On the other hand, the lowest bacterial diversity was detected on the three-month hypochlorite-treated BioCleanEco specimens.

In addition to decreasing the bacterial number, the hypochlorite treatment also changed the species composition forming the biofilm on the surfaces of two antifouling coatings. Whereas mainly Alphaproteobacteria formed the bacterial biofilm in the non-chlorinated system, in the hypochlorite-treated system the relative abundance of Beta- and Gammaproteobacteria increased. Cassé et al. [27] compared the number of microfouling bacteria and the species composition on different coatings in a marine environment. Similar to our experiment, these researchers demonstrated that there was none or only little difference in the number of microfouling bacteria, but the species composition differed between the coatings [27].

The dominant alphaproteobacterial family was Rhodobacteraceae, which has previously been linked especially to early development of biofilm in marine environments, but also detected from this same environment earlier [28-31]. Many bacteria belonging to Rhodobacteraceae are known to perform phototrophic iron oxidation [32]. In addition, it has been speculated that the members of Rhodobacteraceae form the initial biofilm since they are able to survive on nutrient poor conditions of early stages of biofilm formation. Moreover, these microorganisms are capable of forming biofilm on copper-based biocidal antifouling coating $[30,33]$.

Archaeal fouling has not been studied as extensively as bacterial fouling and only few reports describe the archaeal community in marine fouling [2,31]. The family Nitrosopumilus was the most commonly detected archaea. They perform chemoautotrophic ammonia oxidation and could thus be important partners in the biofilm-forming community, providing the source of nitrogen compounds to the other microorganisms [34].

Monoblepharidomycetes and unidentified Ascomycota were the dominant fungi detected. Most aquatic fungi belong to Ascomycetes and Chytridiomycetes, as do the fungi detected here [35]. Only small differences were detected in fungal communities between the control system and the hypochlorite-treated coupons. Similar fungal composition has been reported earlier from the same environment but different from current results; Monoblepharidomycetes were earlier detected only from the hypochlorite-treated environment [31]. Fungi has been connected to deterioration of polymeric coatings [36]. Fungi also exert physical forces, unlike bacteria or archaea, and have the ability to form hyphae, to penetrate hard substrates, and to spread on and through materials [37]. Overall, fungi have an important role in the biofilm since they are able to degrade autochthonous and allochthonous organic matter [35].

The biofouling and biodeterioration of man-made materials, including metal and their alloys, due to biofilm formation has a great environmental and economical implications [38]. Antifouling coatings are widely used on marine structures to control biofouling [39]. Both coatings included in this study were fouling release type of coatings [9]. The effectiveness of most of the non-stick coatings is based on a combination of surface free energy, surface structure, and surface roughness [40]. Here, the anti-fouling coatings alone did not prevent the settlement of microfouling organisms. Since microbial fouling affects the performance of commercial antifouling coatings the quantitative and qualitative analyses of marine microbial fouling communities is of great interest [25,39]. As summarized by Flemming [4], detailed knowledge about biofilms is crucial for understanding and preventing biofouling, as well as to choose a successful anti-fouling strategy. Microorganisms may cause deterioration of polymeric substances, such as the coatings [10]. However, during the relatively short survey time (three months) in this study, no degradation of coatings was evident. Even though the microfouling species would not directly cause deterioration of the coatings, the original surface properties, such as hydrophobicity, can be masked [10]. 
The present study demonstrates that microfouling combined to inorganic fouling was extensive and formed by a diverse group of microorganisms in a cooling water cycle utilizing brackish Baltic Sea water. The composition of a microfouling community, not only the number of microorganisms, has been identified to be an important factor in either promoting or inhibiting the macrofouling settlement depending on the species composition [3]. The hypochlorite treatment combined to anti-fouling coatings proved to be efficient at least during this three-month survey period.

\section{Conclusions}

The microfouling on the surfaces of the studied fouling-release coatings was intensive during the warm summer months. The fouling consisted of both inorganic fouling and biofouling. According to the results presented here, the chlorination reduced the microfouling in the brackish water by 10-1000-fold, but also altered the structure of the remaining microbial community forming the biofilm on the surfaces. The chlorination did not prevent the adhesion, but rather killed the biofouling species after the attachment. The combination of TeknoTar coating and the hypochlorite treatment was most efficient in reducing the attachment of bacteria. The highest bacterial diversity was detected on surfaces of the TeknoTar coating, irrespective to whether they had received a hypochlorite treatment or not, even though the number of bacteria was significantly decreased due to the hypochlorite.

Acknowledgments: Digital, Internet, Materials \& Engineering Co-Creation (DIMECC) as a part of Breakthrough steels and applications program and Teollisuuden voima Oyj (TVO) are thanked for funding this work. The staff of TVO Olkiluoto Nuclear Power Plant is thanked for their help during the sampling, especially Pekka Simula and Merja Levy. Vivi Brooke is thanked for critical language editing.

Author Contributions: Pauliina Rajala, Leena Carpén, Henri Väisänen, and Outi Priha designed the experiments and analyzed the data; Pauliina Rajala, Leena Carpén, and Outi Priha performed the experiments; Irina Tsitko designed and performed the confocal microscopy experiments and analyzed the data; Elina Sohlberg analyzed the sequencing data; Pauliina Rajala, Elina Sohlberg, Outi Priha, Irina Tsitko, Henri Väisänen, Mikko Tausa, and Leena Carpén wrote the paper.

Conflicts of Interest: The authors declare no conflict of interest.

\section{References}

1. Rajagopal, S.; Jenner, H.A.; Vayalam, P.V. Operational and Environmental Consequences of Large Industrial Cooling Water Systems; Springer: New York, NY, USA, 2012.

2. Salta, M.; Wharton, J.A.; Blache, Y.; Stokes, K.R.; Briand, J.F. Marine biofilms on artificial surfaces: Structure and dynamics. Environ. Microbiol. 2013, 15, 2879-2893. [CrossRef] [PubMed]

3. Sawall, Y.; Richter, C.; Ramette, A. Effects of eutrophication, seasonality and macrofouling on the diversity of bacterial biofilms in equatorial coral reefs. PLoS ONE 2012, 7, e39951. [CrossRef] [PubMed]

4. Flemming, H.C. Why micro-organisms live in biofilms and the problem of biofouling. In Marine and Industrial Biofouling; Flemming, H., Murthy, P., Venkatesan, R., Cooksey, K., Eds.; Springer: Berlin, Germany, 2009.

5. Cristiani, P.; Perboni, G. Antifouling strategies and corrosion control in cooling circuits. Bioelectrochemistry 2014, 97, 120-126. [CrossRef] [PubMed]

6. Murthy, P.S.; Venkatesan, R.; Nair, K.V.K.; Inbakandan, D.; Jahan, S.S.; Peter, D.M.; Ravindran, M. Evaluation of sodium hypochlorite for fouling control in plate heat exchangers for seawater application. Int. Biodeterior. Biodegrad. 2005, 55, 161-170. [CrossRef]

7. Jenner, H.A.; Taylor, C.J.L.; van Donk, M.; Khalanski, M. Chlorination by-products in chlorinated cooling water of some European coastal power stations. Mar. Environ. Res. 1997, 43, 279-293. [CrossRef]

8. Sharma, V.K.; Zboril, R.; McDonald, T.J. Formation and toxicity of brominated disinfection byproducts during chlorination and chloramination of water: A review. J. Environ. Sci. Heal. B 2014, 49, 212-228. [CrossRef] [PubMed]

9. Lejars, M.; Margaillan, A.; Bressy, C. Fouling release coatings: A nontoxic alternative to biocidal antifouling coatings. Chem. Rev. 2012, 112, 4347-4390. [CrossRef] [PubMed]

10. Flemming, H. Relevance of biofilms for the biodeterioration of surfaces of polymeric materials. Polym. Degrad. Stab. 1998, 3910, 309-315. [CrossRef] 
11. Little, B.J.; Ray, R.I.; Wagner, P.A.; Jones-Meehan, J.; Lee, C.C.; Mansfeld, F. Spatial relationships between marine bacteria and localized corrosion on polymer coated steel. Biofouling 1999, 13, 301-321. [CrossRef]

12. Dobretsov, S.; Abed, R.M.M.; Teplitski, M. Mini-review: Inhibition of biofouling by marine microorganisms. Biofouling 2013, 29, 423-441. [CrossRef] [PubMed]

13. Rubio, D.; Casanueva, J.F.; Nebot, E. Assessment of the antifouling effect of five different treatment strategies on a seawater cooling system. Appl. Therm. Eng. 2015, 85, 124-134. [CrossRef]

14. Flemming, H.C. Biofouling in water systems-Cases, causes and countermeasures. Appl. Microbiol. Biotechnol. 2002, 59, 629-640. [CrossRef] [PubMed]

15. Muyzer, G.; de Waal, E.C.; Uitierlinden, A.G. Profiling of complex microbial populations by denaturing gradient gel electrophoresis analysis of polymerase chain reaction-amplified genes coding for 16S rRNA. Appl. Environ. Microbiol. 1993, 59, 695-700. [PubMed]

16. Herlemann, D.P.; Labrenz, M.; Jürgens, K.; Bertilsson, S.; Waniek, J.J.; Andersson, A.F. Transitions in bacterial communities along the $2000 \mathrm{~km}$ salinity gradient of the Baltic Sea. ISME J. 2011, 5, 1571-1579. [CrossRef] [PubMed]

17. Klindworth, A.; Pruesse, E.; Schweer, T.; Peplies, J.; Quast, C.; Horn, M.; Glöckner, F.O. Evaluation of general 16S ribosomal RNA gene PCR primers for classical and next-generation sequencing-based diversity studies. Nucleic Acids Res. 2013, 41, e1-e11. [CrossRef] [PubMed]

18. Gardes, M.; Bruns, T.D. ITS primers with enhanced specificity for basidiomycetes-Application to the identification of mycorrhizae and rusts. Mol. Ecol. 1993, 2, 113-118. [CrossRef] [PubMed]

19. Caporaso, J.G.; Kuczynski, J.; Stombaugh, J.; Bittinger, K.; Bushman, F.D.; Costello, E.K.; Fierer, N.; Peña, A.G.; Goodrich, J.K.; Gordon, J.I.; et al. QIIME allows analysis of high-throughput community sequencing data. Nat. Methods 2010, 7, 335-336. [CrossRef] [PubMed]

20. Edgar, R.C. Search and clustering orders of magnitude faster than BLAST. Bioinformatics 2010, 26, $2460-2461$. [CrossRef] [PubMed]

21. DeSantis, T.Z.; Hugenholtz, P.; Larsen, N.; Rojas, M.; Brodie, E.L.; Keller, K.; Huber, T.; Dalevi, D.; Hu, P.; Andersen, G.L. Greengenes, a chimera-checked $16 \mathrm{~S}$ rRNA gene database and workbench compatible with ARB. Appl. Environ. Microbiol. 2006, 72, 5069-5072. [CrossRef] [PubMed]

22. Kõljalg, U.; Nilsson, R.H.; Abarenkov, K.; Tedersoo, L.; Taylor, A.F.S.; Bahram, M.; Bates, S.T.; Bruns, T.D.; Bengtsson-Palme, J.; Callaghan, T.M.; et al. Towards a unified paradigm for sequence-based identification of fungi. Mol. Ecol. 2013, 22, 5271-5277. [CrossRef] [PubMed]

23. Wang, Q.; Garrity, G.M.; Tiedje, J.M.; Cole, J.R. Naive Bayesian classifier for rapid assignment of rRNA sequences into the new bacterial taxonomy. Appl. Environ. Microbiol. 2007, 73, 5261-5267. [CrossRef] [PubMed]

24. Molino, P.J.; Campbell, E.; Wetherbee, R. Development of the initial diatom microfouling layer on antifouling and fouling-release surfaces in temperate and tropical Australia. Biofouling 2009, 25, 685-694. [CrossRef] [PubMed]

25. Muthukrishnan, T.; Abed, R.M.M.; Dobretsov, S.; Kidd, B.; Finnie, A.A. Long-term microfouling on commercial biocidal fouling control coatings. Biofouling 2014, 30, 1155-1164. [CrossRef] [PubMed]

26. Briand, J.-F.; Djeridi, I.; Jamet, D.; Coupé, S.; Bressy, C.; Molmeret, M.; Le Berre, B.; Rimet, F.; Bouchez, A.; Blache, Y. Pioneer marine biofilms on artificial surfaces including antifouling coatings immersed in two contrasting French Mediterranean coast sites. Biofouling 2012, 28, 453-463. [CrossRef] [PubMed]

27. Casse, F.; Swain, G.W. The development of microfouling on four commercial antifouling coatings under static and dynamic immersion. Int. Biodeterior. Biodegrad. 2006, 57, 179-185. [CrossRef]

28. Dang, H.; Lovell, C.R. Bacterial primary colonization and early succession on surfaces in marine waters as determined by amplified rRNA gene restriction analysis and sequence analysis of 16S rRNA genes. Appl. Environ. Microbiol. 2000, 66, 467-475. [CrossRef] [PubMed]

29. Jones, P.R.; Cottrell, M.T.; Kirchman, D.L.; Dexter, S.C. Bacterial community structure of biofilms on artificial surfaces in an estuary. Microb. Ecol. 2007, 53, 153-162. [CrossRef] [PubMed]

30. Elifantz, H.; Horn, G.; Ayon, M.; Cohen, Y.; Minz, D. Rhodobacteraceae are the key members of the microbial community of the initial biofilm formed in Eastern Mediterranean coastal seawater. FEMS Microbiol. Ecol. 2013, 85, 348-357. [CrossRef] [PubMed] 
31. Rajala, P.; Bomberg, M.; Huttunen-Saarivirta, E.; Priha, O.; Tausa, M.; Carpén, L. Influence of chlorination and choice of materials on fouling in cooling water system under brackish seawater conditions. Materials 2016, 9, 475. [CrossRef]

32. Hedrich, S.; Schlömann, M.; Barrie Johnson, D. The iron-oxidizing proteobacteria. Microbiology 2011, 157, 1551-1564. [CrossRef] [PubMed]

33. Chen, C.L.; Maki, J.S.; Rittschof, D.; Teo, S.L.M. Early marine bacterial biofilm on a copper-based antifouling paint. Int. Biodeterior. Biodegrad. 2013, 83, 71-76. [CrossRef]

34. Usher, K.M.; Kaksonen, A.H.; MacLeod, I.D. Marine rust tubercles harbour iron corroding archaea and sulphate reducing bacteria. Corros. Sci. 2014, 83, 189-197. [CrossRef]

35. Grossart, H.P.; Rojas-Jimenez, K. Aquatic fungi: Targeting the forgotten in microbial ecology. Curr. Opin. Microbiol. 2016, 31, 140-145. [CrossRef] [PubMed]

36. Little, B.J.; Ray, R.I. The Role of Fungi in Microbiologically Influenced Corrosion. In Proceedings of the 15th International Corrosion Congress, Granada, Spain, 22-27 September 2002.

37. Sterflinger, K. Fungi as geologic agents. Geomicrobiol. J. 2000, 17, 97-124. [CrossRef]

38. Koch, G.H.; Brongers, M.P.; Thompson, N.G.; Virmani, Y.P.; Payer, J. Corrosion Cost and Preventative Strategies in the United States; Report No. FHWA-RD-01; National Technical Information Service: Alexandria, VA, USA, 2002.

39. Yebra, D.M.; Kiil, S.; Dam-Johansen, K. Antifouling technology-Past, present and future steps towards efficient and environmentally friendly antifouling coatings. Prog. Org. Coat. 2004, 50, 75-104. [CrossRef]

40. Watermann, B.; Berger, H.; Sonnichsen, H.; Willemsen, P. Performance and effectiveness of non-stick coatings in seawater. Biofouling 1997, 11, 101-118. [CrossRef]

(C) 2016 by the authors; licensee MDPI, Basel, Switzerland. This article is an open access article distributed under the terms and conditions of the Creative Commons Attribution (CC-BY) license (http:/ / creativecommons.org/licenses/by/4.0/). 